\title{
Labile carbon supplement induces growth of filamentous bacteria in the Baltic Sea
}

\author{
H. Tammert ${ }^{1,2}$, R. Lignell ${ }^{3}$, V. Kisand ${ }^{2}$, K. Olli ${ }^{1, *}$ \\ ${ }^{1}$ Institute of Ecology and Earth Sciences, University of Tartu, Lai 40, Tartu 51005, Estonia \\ ${ }^{2}$ Institute of Technology, University of Tartu, Nooruse 1, Tartu 50411, Estonia \\ ${ }^{3}$ Finnish Institute of Marine Research, PO Box 33, 00931 Helsinki, Finland
}

\begin{abstract}
A 3 wk experiment with 9 mesocosms $\left(51 \mathrm{~m}^{3}\right)$ was carried out at a coastal site of the brackish northwest Gulf of Finland (Baltic Sea) to study the effects of nutrient limitation and labile carbon $(\mathrm{C})$ amendment on the plankton community. A $5 \mathrm{~d}$ period with daily inorganic nitrogen $(\mathrm{N})$ and phosphorus (P) additions boosted algal biomass increase and the demand for mineral nutrients. In the following $2 \mathrm{wk}$, the supply of 1 nutrient was cut, while keeping or increasing the other, thus inducing a gradient of nutrient-limitation regimes. Labile organic C (glucose) was added to increase bacterial growth and induce mineral nutrient competition between bacteria and algae. Here we report the effects of the treatments on bacterial abundance, production, and community composition. Addition of labile organic $\mathrm{C}$ led to a significant increase $(\mathrm{p}<0.001)$ in the biomass of large filamentous bacteria and in bacterial productivity but not in the biomass of small coccoid bacteria. Addition of inorganic N and P did not have any clear-cut effect on bacterioplankton. Our results suggest that bacterial assemblages have the capacity to respond to enhanced substrate availability, and that glucose strongly enhances the development of filamentous bacteria, with implications for food-web structure, biodiversity, and biogeochemistry.
\end{abstract}

KEY WORDS: Bacteria $\cdot$ Nutrient limitation $\cdot$ Community composition $\cdot$ Denaturing gradient gel electrophoresis $\cdot$ DGGE $\cdot$ Cell size $\cdot$ Baltic Sea

\section{INTRODUCTION}

Changes in bacterial community composition, abundance, activity, and ecophysiology are driven by resource availability (Bratbak \& Thingstad 1985, Riemann et al. 2000, Lignell et al. 2008) as well as predation and viral lysis (Øvreås et al. 2003, Alonso-Saez et al. 2009). Coupling between growth, productivity and genetic and functional diversity of bacteria has been studied in both natural and experimental systems (Parsons et al. 1981, Muyzer et al. 1993, Tuomi et al. 1999, Bernard et al. 2001). In the era of anthropogenic eutrophication and expanding algal blooms in coastal waters (Smayda 2002), the response of bacteria to increased nutrient and substrate availability can have a profound effect on food-web structure and biogeochemical cycles.

In the pelagic photic zone, mineral nutrient limitation is a fundamental controlling factor for the community composition of osmotrophic microorganisms (organisms that feed on dissolved substrates). In addition to resource competition between different trophic levels, changes in the morphology of species and individual organisms determine the competitive ability within the trophic level (Øvreås et al. 2003, Corno \& Jürgens 2006).

Bacterial cell size plays a central role in resource competition, as the surface:volume ratio relates to diffusive nutrient transport towards the organism (Jumars et al. 1993). Predation losses are also size- 
dependent, as increase in size, filamentation, and aggregation are means to reduce predation (Fenchel 1980, Smetacek et al. 2004). Equally, miniaturization and extremely small size is a refuge from predation (Boenigk et al. 2004). In the nutrient uptake and predator-prey context, these bacterial strategies have been conventionally seen as a trade-off, with small cells representing the uptake specialists, and large cells avoiding intensive grazing pressure from small protozoa, thus representing the predator defense specialists (Fenchel 1980, Koch 1996).

The relative success of competition and defense specialists depends on the nutrient conditions. Thingstad et al. (2005) argued that it is the 'surface: cell requirement of limiting element' ratio, rather than the surface: volume ratio, that is important. Any strategy by which cell size can be increased at the expense of a non-limiting resource gives a competitive advantage, provided that the cellular requirement for the limiting nutrient does not increase proportionally (Thingstad et al. 2005). In the latter case, increasing cell size would simultaneously give the species the benefits of both strategies: (1) increasing resource competitiveness by increasing cell surface area and (2) alleviating predator vulnerability by increasing the cell size.

During phytoplankton blooms, bacterial community composition undergoes temporal changes (Larsen et al. 2004, Rink et al. 2007). Induction of phytoplankton blooms and increased availability of distinct dissolved organic carbon (DOC) components select for specific bacterial populations (Øvreås et al. 2003). Amendment of the labile $\mathrm{C}$ substrate has induced shifts in bacterial community structure and growth of large-celled bacterial species in coastal mesocosm experiments (Havskum et al. 2003, Øvreås et al. 2003, Alonso-Saez et al. 2009). Electron microscopy analysis of the large cells has revealed intracellular inclusions with unusually high carbon:nitrogen: phosphorus (C:N:P) ratios, suggesting that the large size is associated with luxurious $C$ storage and uptake (Fagerbakke et al. 1996).

Only a few studies on bacterial community composition are available from the central Baltic Sea (Riemann et al. 2008, Andersson et al. 2010, Herlemann et al. 2011) and the Gulf of Bothnia (Pinhassi et al. 1997, Hagström et al. 2000). In the present study, we examined the response of bacterioplankton to different substrate and nutrient manipulations during a developing summer cyanobacterial bloom in a largescale experiment. The mesocosm experiment in the naturally N-limited coastal Baltic Sea was used as a model system to examine the response of the plank- ton community to changes in external nutrient supply rates and to an induced limitation gradient of either $\mathrm{N}$ or $\mathrm{P}$. We expected that labile $\mathrm{C}$ addition would promote bacterial production (BP) and escalate mineral nutrient limitation, as well as cause changes in the bacterial community composition. Nutrient limitation patterns in mesocosms are dealt with in great detail by Tanaka et al. (2006) and the response of phytoplankton by Kangro et al. (2007). In the present study we demonstrate changes in bacterial activity, abundance, biomass, cell morphology, and community composition as a response to nutrient and labile $\mathrm{C}$ manipulations.

\section{MATERIALS AND METHODS}

\section{Experimental set-up}

The mesocosm experiment was carried out from 1 to 22 July 2003, in a sheltered archipelago site near the Tvärminne Zoological Station (University of Helsinki, Finland), northwestern Gulf of Finland (59 51' $20^{\prime \prime} \mathrm{N}, 2^{\circ} 15^{\prime} 45^{\prime \prime} \mathrm{E}$ ). A natural water column was enclosed in 9 floating transparent plastic bags (double-layered polyethylene with glass-fiber reinforcements), each with a total volume of $51 \mathrm{~m}^{3}$ (diameter $2.3 \mathrm{~m}$; $12 \mathrm{~m}$ deep main cylindrical part and $2 \mathrm{~m}$ conical bottom part). The mesocosms were fastened to wooden rafts and connected separately to a central buoy (distance ca. $30 \mathrm{~m}$ from each mesocosm) to ensure even light conditions. The enclosures were loosely covered with polyethylene lids to allow air exchange, but prevent contamination by sea birds and atmospheric wet deposition of nutrients.

The general experimental idea was to induce an algal bloom in all units except the control by daily addition of inorganic $\mathrm{N}$ and $\mathrm{P}$ in Redfield ratio ( $\mathrm{N}$ added at $1 \mu \mathrm{mol} \mathrm{NH}_{4} \mathrm{Cl}-\mathrm{N} \mathrm{l}^{-1} \mathrm{~d}^{-1}, \mathrm{P}$ added at $0.06 \mu \mathrm{mol}$ $\mathrm{KH}_{2} \mathrm{PO}_{4}-\mathrm{P} \mathrm{l}^{-1} \mathrm{~d}^{-1}$ ) during the first $5 \mathrm{~d}$ (hereinafter referred to as the 'boosting period'). We expected the algal bloom to increase inorganic nutrient demand. A limitation gradient of either $\mathrm{N}$ or $\mathrm{P}$ was induced over the next 2 wk ('experimental period') by changing the nutrient supply ratios from completely cutting the supply of either nutrient (defining the limiting nutrient), while continuing or increasing the supply of the other (Table 1). Labile DOC (13.3 $\mu \mathrm{mol}$ glucose-C $\mathrm{1}^{-1}$ $\mathrm{d}^{-1}$ ) was supplied into 3 mesocosms ('glucose mesocosms') during the experimental period to stimulate bacterial growth and further intensify nutrient limitation. One control mesocosm was not manipulated throughout the experiment (Table 1). 
Table 1. Design of the mesocosm experiment. Daily nutrient supply rates to the mesocosms: $\mathrm{N}$ : $1 \mu \mathrm{mol} \mathrm{NH} \mathrm{N}_{4} \mathrm{l}^{-1} \mathrm{~d}^{-1}$; P: $0.06 \mu \mathrm{mol} \mathrm{PO} \mathrm{I}^{-1} \mathrm{~d}^{-1}$; glucose (G): $13.25 \mu \mathrm{mol}$ glucose- $\mathrm{C}^{-1}$ $\mathrm{d}^{-1} ; 5 \times \mathrm{N}$ and $5 \times \mathrm{P}$ denote 5 times the amount of $\mathrm{N}$ and $\mathrm{P}$, respectively

\begin{tabular}{|lccc|}
\hline $\begin{array}{l}\text { Mesocosm } \\
\text { no. }\end{array}$ & $\begin{array}{c}\text { Mesocosm } \\
\text { unit }\end{array}$ & $\begin{array}{c}\text { Boosting, } \\
\text { Days 1-5 }\end{array}$ & $\begin{array}{c}\text { Experimental, } \\
\text { Days 6-20 }\end{array}$ \\
\hline 1 & $\mathrm{NP}$ & $\mathrm{N}+\mathrm{P}$ & $\mathrm{N}+\mathrm{P}$ \\
2 & $\mathrm{~N}$ & $\mathrm{~N}+\mathrm{P}$ & $\mathrm{N}$ \\
3 & $\mathrm{P}$ & $\mathrm{N}+\mathrm{P}$ & $\mathrm{P}$ \\
4 & $5 \mathrm{~N}$ & $\mathrm{~N}+\mathrm{P}$ & $5 \times \mathrm{N}$ \\
5 & $5 \mathrm{P}$ & $\mathrm{N}+\mathrm{P}$ & $5 \times \mathrm{P}$ \\
6 & $5 \mathrm{NG}$ & $\mathrm{N}+\mathrm{P}$ & $5 \times \mathrm{N}+\mathrm{G}$ \\
7 & $5 \mathrm{PG}$ & $\mathrm{N}+\mathrm{P}$ & $5 \times \mathrm{P}+\mathrm{G}$ \\
8 & $\mathrm{NPG}$ & $\mathrm{N}+\mathrm{P}$ & $\mathrm{N}+\mathrm{P}+\mathrm{G}$ \\
9 & Control & $\mathrm{None}$ & None \\
\hline
\end{tabular}

\section{Sampling}

Discrete water-column samples from 0 to $7 \mathrm{~m}$ were taken at $1 \mathrm{~m}$ depth intervals with a 51 volume Limnostype cylindrical tube sampler and pooled thereafter into 1 vertically integrated $40 \mathrm{l}$ composite sample. All sampling was done in the morning from 07:00 to $08: 00 \mathrm{~h}$ (local time) prior to the daily enrichments from 10:00 to 11:00 h (for details see Olli \& Seppälä 2001). During sampling, temperature was measured manually (with a thermometer connected to the sampler) at $3 \mathrm{~m}$ depth, supplemented with occasional CTD (conductivity, temperature and depth sensor) profiles (SIS 100 PLUS CTD). Dissolved mineral nutrients $\left(\mathrm{NO}_{2}-\mathrm{N}+\right.$ $\mathrm{NO}_{3}-\mathrm{N}, \mathrm{PO}_{4}-\mathrm{P}, \mathrm{NH}_{4}-\mathrm{N}$ ) were analyzed manually on a Hitachi U-1800 spectrophotometer using the colorimetric methods of Grasshoff et al. (1983).

\section{Total number of bacteria and bacterial biomass}

Formalin-preserved aliquots (3 to $5 \mathrm{ml}$ ) were stained with DAPI $\left(4{ }^{\prime}, 6\right.$-diamidino-2-phenylindole; PolySciences; final concentration: $10 \mu \mathrm{g} \mathrm{ml}^{-1}$ ) for 5 min in the dark, filtered onto black membrane filters (Osmonics, $0.22 \mu \mathrm{m}$ pore size), air-dried, mounted into immersion oil, and covered with a cover slip. The slides were kept frozen $\left(-22^{\circ} \mathrm{C}\right)$ and dark until counting. At least 250 bacteria on 25 fields were counted using a Leica DMRB epifluorescence microscope with UV-violet excitation light and 100x oil immersion objective.

Heterotrophic bacterial cells were divided into 2 categories based on the differences in cell morphology. Round-shaped bacteria $<3 \mu \mathrm{m}$ were defined as nonfilamentous, while cells longer than $3 \mu \mathrm{m}$ were defined as filamentous bacteria. The biomass of nonfilamentous bacteria (BBCocc) was calculated using a C content of $18.5 \mathrm{fg} \mathrm{C}^{\mathrm{C}} \mathrm{cell}^{-1}$ (local estimate for summer; unpubl. results). The biomass of filamentous bacteria (BBfila) was calculated using cell volume, obtained by measuring the dimensions of the fila-

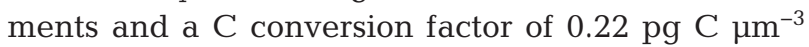
(Bratbak 1985). Cells in each sample were measured on 40 microscopic fields with an ocular micrometer assuming a cylindrical geometry of the filaments.

\section{Bacterial productivity}

Net BP was measured using a modified ${ }^{3} \mathrm{H}$-thymidine method (Riemann et al. 1987), the cells being separated from the liquid phase by centrifugation (Smith \& Azam 1992). Triplicate subsamples (each $1 \mathrm{ml}$ ) and 1 formalin-killed blank ( $2 \%$ final concentration) per mesocosm were dispensed into sterilized Eppendorf tubes after addition of ${ }^{3} \mathrm{H}$-thymidine $(\mathrm{TdR}$, specific activity ca. $80 \mathrm{Ci} \mathrm{mmol}^{-1}, 10 \mathrm{nmol} \mathrm{l}^{-1}$ final concentration; NEN Products). The samples were incubated at in situ temperature for $1 \mathrm{~h}$, then killed with formalin, extracted with TCA (5\% final concentration) on ice for $30 \mathrm{~min}$, and centrifuged in a precooled centrifuge at $16000 \times g, 0^{\circ} \mathrm{C}$ for $10 \mathrm{~min}$. The supernatant was carefully aspirated and the bacterial pellet was vortexed with $1 \mathrm{ml}$ ice-cold $5 \%$ TCA, then centrifuged again. The supernatant was removed and $1 \mathrm{ml}$ scintillation cocktail (Insta-Gel plus, Packard) was added for radioactivity measurements using a Wallace Win Spectral 1414 liquid scintillation counter. Net BP was then estimated, applying the ${ }^{3} \mathrm{H}$-thymidine conversion factor of $1.1 \times 10^{-18}$ cells $\mathrm{mol}^{-1} \mathrm{TdR}$ (Riemann et al. 1987) and C content of $18.5 \mathrm{fg} \mathrm{C} \mathrm{cell}^{-1}$ as in 'Total number of bacteria and bacterial biomass'.

\section{Biomass of phytoplankton, heterotrophic nanoflagellates, and ciliates}

Phytoplankton and ciliates were counted from acid Lugol fixed samples with a settling chamber method under a Leica DMIL inverted microscope (200 or 400x magnification), as described in Kangro et al. (2007). The biovolumes of the cells were calculated by using approximate stereometrical bodies and were expressed as wet weight applying a density of 1 . Autotrophic and heterotrophic (HNF) nanoflagellates were counted from glutaraldehyde (final concentra- 
tion: $2.5 \%$ ) fixed samples followed by DAPI staining under the epifluorescence microscope. Autotrophic flagellates were distinguished based on the chlorophyll fluorescence under green $(546 / 565 \mathrm{~nm}$, OG 590) and blue excitation light (470/505 nm, OG 515).

\section{DNA extraction and PCR-DGGE}

Aliquots $(100 \mathrm{ml})$ were filtered onto $0.22 \mu \mathrm{m}$ pore filters (Poretics, $47 \mathrm{~mm}$ diameter). Nucleic acids were extracted using an SDS-polyphosphate buffer for lysis, zirconia beads for bead-beating, and phenolchloroform for extraction as described by Stevens et al. (2005). The Bacteria-specific primers GM5F (341F, with GC-clamp) and DS907RM were used to amplify fragments of about 550 bp by PCR using an Eppendorf Mastercycler with RedTaq ${ }^{\mathrm{TM}}$ (Sigma). Denaturing gradient gel electrophoresis (DGGE) was performed with a D-Code System (Bio-Rad) or DGGEK-1001-220 (CBS Scientific) according to Brinkhoff \& Muyzer (1997), using a 20-70\% denaturing urea-formamide gradient on a polyacrylamide gel for $20 \mathrm{~h}$ at $100 \mathrm{~V}$ constant voltage. Gels were stained with SYBR Gold (Molecular Probes) and visualized by a BioDoc Analyse Transilluminator (Biometra) or Typhoon Trio (Amersham).

Each band (DNA fragment traveling to a particular position) was assumed to represent an operational taxonomic unit (OTU). Each gel contained 2 additional lanes with 3 standard bands for fitting and normalizing different gel runs. Banding patterns were compared using band positions. Binary coding (1: band existing, 0: no band) was used to create a data matrix (Jaccard similarity matrix), which was analyzed by correspondence analysis (CA) to create a low-dimensional space of significant variation in the data matrix (ordination). Sample scores were used to analyze the statistical differences between samples with respect of community diversity. These differences (samples grouped by nutrient treatments as described above) were subjected to multivariate discriminant analysis, and statistical significance was tested by the multivariate randomization test (1000 permutations).

\section{Sequencing of PCR-DGGE bands}

DNA bands were excised from the DGGE gels with sterile pipette tips, and small pieces of acrylamide gel were placed in $20 \mu \mathrm{l}$ sterile water and allowed to release solutes by diffusion overnight at $4^{\circ} \mathrm{C}$. DNA bands from different samples (lanes) were re-amplified using the primers GM5F and DS907RM. The PCR products were purified with Quantum Prep PCR Kleen spin columns (Bio-Rad) and cloned into the pGEM Easy-T vector system (Promega). Clone identity was confirmed by a re-run of the DGGE gel to determine that their positions accorded with the bands that had been excised. The PCR products were then purified with Quantum Prep PCR Kleen spin columns and directly sequenced using the Applied Biosystem 3730XL according to the manufacturer's directions.

The accession numbers of all the DGGE bands sequenced (EU878136 to EU878168) can be found at the GenBank website. The phylogeny of the sequences obtained was determined using nucleotide search at NCBI. Detailed phylogenetic analysis was performed with ARB software (Brinkhoff \& Muyzer 1997) using integrated aligner and ARB parsimony (Ludwig et al. 2004). The 16S rRNA global tree was based on the ARB database ssu_jan04_corr_opt.

\section{Data analysis}

Statistical analyses were conducted using the $\mathrm{R}$ software environment for statistical computing ( $R$ Development Core Team 2011). To elucidate the effect of treatments to the bacterioplankton properties we first removed the overall non-linear time effect by fitting a generalized additive model (GAM) to the data. Thereafter we extracted the detrended residuals of the GAM models for further analysis with generalized least-squares fitted linear models (gls). To analyze the effect of mineral nutrient and labile $\mathrm{C}$ amendment, we used only the experimental period (Days 7 to 21). Treatments were coded as 2-level factors and time was a continuous explanatory variable. Single and 5-times supply rates of mineral nutrients were pooled in the statistical analysis, as the effect size and direction were not different.

Data are presented as parameter estimates of the linear models, showing the direction and strength of the treatment effects on the overall time trend, which averaged zero due to the GAM detrending, and the associated significance levels. Treatment interaction effects were not significant and are excluded from the models. To account for temporal autocorrelation in the data we used first-order autocorrelation structure in the models (corAR1). Variance structure (varFixed) was used to account for increasing variance of the data during the course of the mesocosm 
experiment. We considered other correlation and variance structures, but as they did not improve the models, we choose the simpler ones.

For CA, the ade4 library of the R software was used.

\section{RESULTS}

\section{Physical conditions and nutrient dynamics}

Following an onset of atmospheric high pressure, the surface water temperature increased from $15.3^{\circ} \mathrm{C}$ at the start of the experiment to $17.8^{\circ} \mathrm{C}$ during the first week, and reached $22.4^{\circ} \mathrm{C}$ during the third week. Due to thermal conductivity, the temperatures inside the mesocosms closely followed the outside environment (Olli et al. 1996). Salinity was $5.79 \pm$ 0.04 (mean $\pm \mathrm{SD}$ ) without significant stratification or difference between the enclosures. The background nitrate plus nitrite concentration, which initially averaged $0.09 \pm 0.01 \mu \mathrm{mol} \mathrm{l}^{-1}$, varied between 0.2 and $0.3 \mu \mathrm{mol} \mathrm{l}^{-1}$ during the rest of the experiment.

Table 2 shows the average dissolved inorganic $\mathrm{N}$ and $\mathrm{P}$ concentrations and nutrient ratios during the second half of the experiment. After the boosting period, ammonium and phosphate (initially $0.1 \pm 0.03$ and $0.2 \pm 0.01 \mu \mathrm{mol} \mathrm{l}^{-1}$, respectively) varied according to the manipulations. Ammonium remained $<0.3 \mu \mathrm{mol} \mathrm{l}^{-1}$ in all mesocosms, except in the $5 \mathrm{~N}$ and 5 NG units, where it accumulated $\left(>5 \mu \mathrm{mol} \mathrm{l}^{-1}\right)$. Phosphate remained $<0.1 \mu \mathrm{mol} \mathrm{l^{-1 }}$, except in the $\mathrm{P}$ unit ( 0.2 to $0.5 \mu \mathrm{mol} \mathrm{l}^{-1}$ ) and the 5P and 5PG units $\left(>1 \mathrm{~mol} \mathrm{l}^{-1}\right.$ ). The mineral dissolved $\mathrm{N}: \mathrm{P}$ ratio (initially 0.9 ) ranged from 0.5 to 0.7 (5P and 5PG units) to $>100$ (5N and 5NG units) after the boosting period (Table 2).

\section{Phytoplankton biomass}

During the boosting period, the phytoplankton C biomass increased from initially $38 \pm 6$ to $128 \pm 9 \mu \mathrm{g}$ $\mathrm{C}^{-1}$ in the nutrient-enriched mesocosms, corresponding to a chlorophyll a increase from ca. $3.5 \pm$ 0.14 to $19 \pm 1.7 \mathrm{\mu g} \mathrm{l}^{-1}$ (Kangro et al. 2007). Filamentous diazotrophic cyanobacteria (Aphanizomenon sp., Anabaena spp., Nodularia sp.) became the predominant group in all enclosures, increasing from an initial range of $14-30 \%$ to $60-93 \%$ of the total phytoplankton biomass by the end of the experiment (Fig. 1). The response of phytoplankton to nutrient manipulations is detailed in Kangro et al. (2007) and Olli et al. (2005).
Table 2. Concentrations of dissolved inorganic nitrogen (DIN: $\mathrm{NH}_{4}+\mathrm{NO}_{2}+\mathrm{NO}_{3}$ ), phosphorus (DIP: $\mathrm{PO}_{4}$ ) and DIN:DIP ratio in the mesocosms during the second half of the experiment (Days 11 to 21$) ;$ means $\pm \mathrm{SD}$

\begin{tabular}{|lccc|}
\hline Treatment & DIN $\left(\mu \mathrm{mol} \mathrm{l}^{-1}\right)$ & DIP $\left(\mu \mathrm{mol} \mathrm{l}^{-1}\right)$ & DIN:DIP \\
\hline 5N, 5NG & $8.5 \pm 2.9$ & $0.09 \pm 0.03$ & $111.3 \pm 53.7$ \\
N & $0.6 \pm 0.5$ & $0.08 \pm 0.02$ & $8.1 \pm 6.3$ \\
Control & $0.5 \pm 0.2$ & $0.08 \pm 0.02$ & $6.2 \pm 1.8$ \\
NP, NPG & $0.5 \pm 0.2$ & $0.10 \pm 0.03$ & $5.5 \pm 2.2$ \\
P & $0.5 \pm 0.1$ & $0.44 \pm 0.13$ & $1.2 \pm 0.7$ \\
5P, 5PG & $0.5 \pm 0.1$ & $1.18 \pm 0.50$ & $0.6 \pm 0.6$ \\
\hline
\end{tabular}

\section{Treatment effects on bacterioplankton}

The variation in bacterial abundance, biomass, and production are shown in Figs. $1 \& 2$. Boosting increased bacterial biomass (BB) from the initial $28.3 \pm$ 3.1 to $55.1 \pm 3.7 \mu \mathrm{g} \mathrm{Cl}^{-1}$, and BP from $4.7 \pm 0.7$ to $21 \pm$ $2.1 \mu \mathrm{g} \mathrm{Cl}^{-1} \mathrm{~d}^{-1}$.

Glucose addition had a strong positive effect $(\mathrm{p}<$ 0.001) on BBfila (up to $200 \mu \mathrm{g} \mathrm{Cl}^{-1}$ ) and their proportion increased up to $84 \%$ (Fig. 2B). Since the start of the glucose amendment, filamentous bacteria constituted on average $57 \pm 17 \%$ of the total BB in the glucose mesocosms, as opposed to $2.5 \pm 3.2 \%$ in the others. Glucose addition increased BP, total BB, and BBfila (Fig. 2), but had a slight, though significant negative effect on the abundance of coccoid and total number of bacteria (Table 3).

The response of bacteria to mineral nutrients was less clear. P amendment increased BBcocc and total bacterial abundance, while addition of $\mathrm{N}$ had no significant effect (Table 3). The increase in BBfila tended to be higher when glucose was added in combination with $\mathrm{N}$ than with $\mathrm{P}$, but the effect was not statistically significant. The increasing temperature and excessive dominance of diazotrophic cyanobacteria towards the end of the experiment changed the growth conditions for heterotrophic bacteria and probably confounded the treatment effects of $\mathrm{N}$ addition. For example, BP was initially higher in the NG and NPG treatments compared to the PG treatment, but the difference disappeared by the end of the experiment, possibly due to the increasing availability of $\mathrm{N}$ mediated by the diazotrophic cyanobacteria in all treatments.

\section{Bacterioplankton composition}

Bacterial communities were analyzed in 35 samples on 4 sampling days: 1, 5, 11, and 17 (Figs. 3 


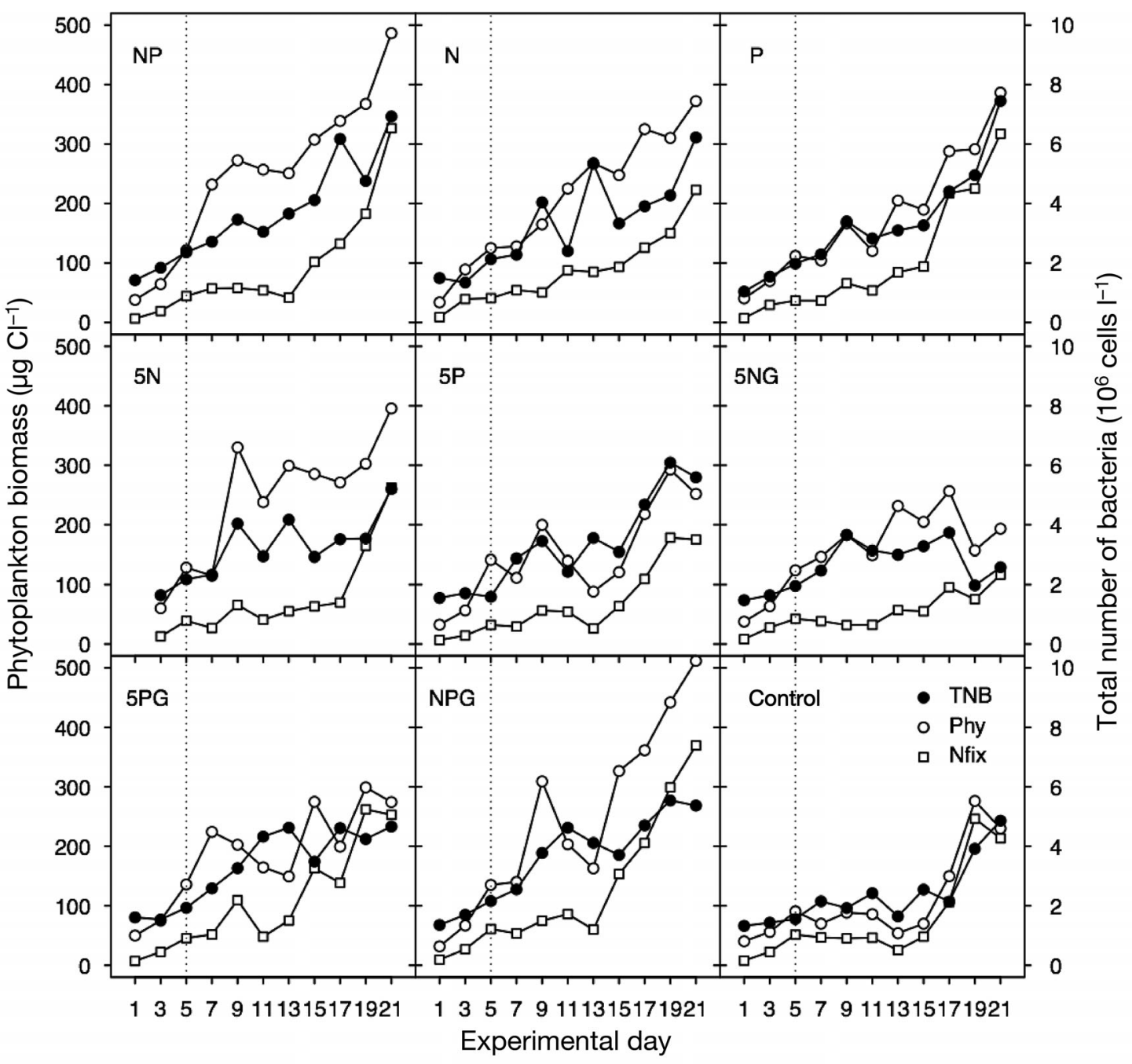

Fig. 1. Response of the total number of bacteria (TNB) and the biomass of total phytoplankton (Phy) and diazotrophic cyanobacteria (Nfix) to nutrient and glucose treatments. Vertical dashed line separates boosting and experimental periods. Treatment abbreviations as in Table 1

\& 4). In total, 71 phylotypes were determined based on DGGE band patterns. The 2 most common phylotypes were observed in 20 and 21 of the 35 samples. Almost half the phylotypes (33) were rare and observed in only 1 to 3 samples. CA analysis revealed that sampling day had the strongest effect on bacterial community composition (Fig. 4). However, glucose addition also had a significant effect (permutations test, $\mathrm{p}<0.05$ ) on bacterial community composition.

\section{Identity of DGGE bands}

In total, 71 cloned bands were sequenced, and 33 unique phylotypes were identified after comparison of forward and reverse sequence runs (Appendix 1).
Major phylogenetic groups such as Alpha- and Betaproteobacteria, Bacteroidetes, and Actinobacteria were identified. In addition, algal plastids (2 different sequences) and genomic $16 \mathrm{~S}$ rDNA of 3 cyanobacteria (genera Anabaena, Pseudanabaena, and Limnothrix) were found among the intense DGGE bands. The most diverse group of bacteria was Bacteroidetes $(\mathrm{n}=15)$. Other groups were equally represented: 4 Actinobacteria and 4 Alpha- and 5 Betaproteobacteria phylotypes.

\section{Identity of DGGE bands in glucose mesocosms}

Glucose treatment led to lower diversity compared to other mesocosms and no unique phylotypes were observed. Six of the bands were Bacteroidetes 


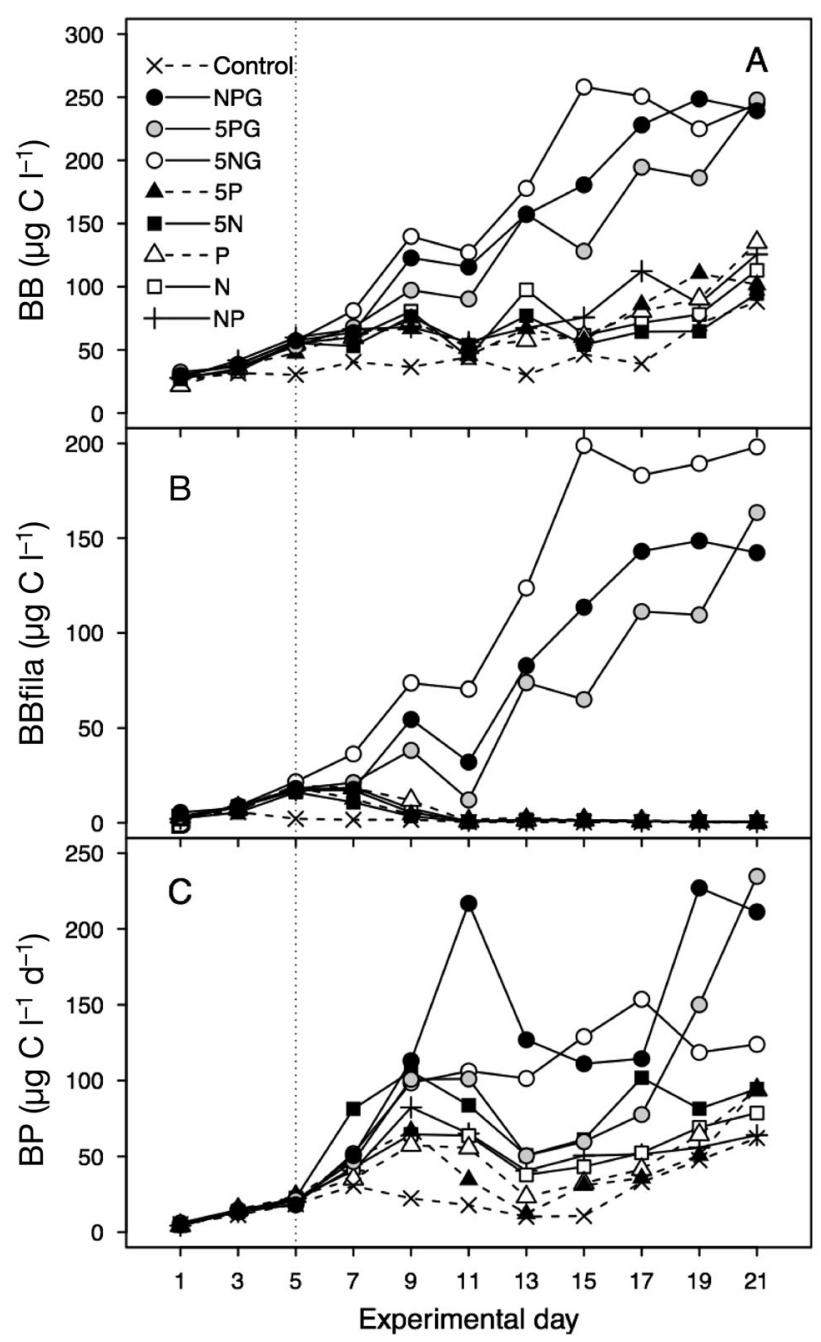

Fig. 2. Response of (A) total bacterial biomass (BB), (B) biomass of filamentous bacteria (BBfila), and (C) bacterial production (BP) to nutrient and glucose treatments. Vertical dashed line separates boosting and experimental periods.

Treatment abbreviations as in Table 1

Table 3. Parameter estimates $( \pm \mathrm{SE})$ of generalized leastsquares models showing the contribution of treatments to the slope of the linear trend for total number of bacteria (TNB), bacterial production (BP), total bacterial biomass (BB), biomass of coccoid bacteria (BBCocc), and biomass of filamentous bacteria (BBfila). $\mathrm{N}$ : $\mathrm{NH}_{4}$ addition, $\mathrm{P}: \mathrm{PO}_{4}$ addition, $\mathrm{G}$ : glucose addition. ${ }^{*} \mathrm{p}<0.005,{ }^{* *} \mathrm{p}<0.001$

\begin{tabular}{|lccc|}
\hline & $\mathrm{N}$ & $\mathrm{P}$ & $\mathrm{G}$ \\
\hline $\mathrm{TNB}$ & $0.009 \pm 0.017$ & $0.064 \pm 0.017^{* *}$ & $-0.057 \pm 0.017^{*}$ \\
$\mathrm{BP}$ & $-0.12 \pm 0.93$ & $0.74 \pm 0.93$ & $3.55 \pm 0.93^{* *}$ \\
BB & $0.28 \pm 0.51$ & $0.47 \pm 0.51$ & $4.95 \pm 0.51^{* *}$ \\
BBcocc & $0.16 \pm 0.31$ & $1.15 \pm 0.31^{* *}$ & $-1.03 \pm 0.31^{*}$ \\
BBfila & $0.06 \pm 0.41$ & $-0.67 \pm 0.41$ & $5.97 \pm 0.41^{* *}$ \\
\hline
\end{tabular}

(Fig. 3): DL2-4 (GenBank accession no. EU878142, Lewinella sp.), DL5-2 (EU878140, uncultured environmental Sphingobacteriales), DL9-4 (EU878151, uncultured environmental Bacteroidetes), DL27-4 (EU878144, uncultured environmental Flavobacteriaceae), DL35-1 (EU878136, Algoriphagus sp.), and DL42-4 (EU878143, uncultured environmental Sphingobacteriales). Also, Alphaproteobacteria (DL8-5, Roseobacter sp.), Actinobacteria (DL21-5, Aquiluna sp.), and Betaproteobacteria (DL23-11, uncultured environmental Betaproteobacteria) were identified.

\section{Biomass of bacterivores}

Total biomass of HNF varied from 3 to $43 \mu \mathrm{g} \mathrm{C} \mathrm{l}^{-1}$, with peaks on Days 5 and 9 (Fig. 5A), and was dominated by small cells (average size $<4 \mu \mathrm{m}$ ). Ciliate biomass was higher and also had 2 peaks (Fig. 5B), one on Day $9\left(78 \pm 23 \mu \mathrm{g} \mathrm{Cl}^{-1}\right)$ and a second peak on Day $17\left(53 \pm 26 \mu \mathrm{g} \mathrm{Cl}^{-1}\right)$. The first peak was dominated by Tintinnids and Prostomes, and the second peak by Hypotrichs. Nutrient and glucose additions did not have a statistically significant effect on the HNF and ciliate biomasses ( $p>0.05)$.

\section{DISCUSSION}

Adding labile $\mathrm{C}$ stimulated $\mathrm{BP}$, increased $\mathrm{BB}$, and changed the bacterial community structure. The bacteria in the glucose mesocosms that profited most from labile $\mathrm{C}$ treatment were distinguished by filamentous morphology and steady increase in biomass. The proportion of filamentous bacteria increased dramatically as a result of glucose addition. Our results confirmed that bacteria in the northern coastal Baltic Sea are primarily substrate-limited. Lignell et al. (2008) showed that the northern Baltic Sea has a small labile DOC pool $(<1-5 \%$ of total DOC) and low ratios of labile DOC (mol):DON $(\mathrm{mol})=<1$ to $7: 1)$. High biomass of diazotrophic cyanobacteria stimulated the growth of heterotrophic bacteria. This happened probably through the release of some of the fixed $\mathrm{N}$. The build-up phase of the diazotrophic biomass apparently did not supply enough labile organic $\mathrm{C}$ to promote the development of filamentous heterotrophic bacteria, while a decaying Nodularia spumigena bloom supports the development of filamentous bacteria in the Baltic Sea (Engström-Öst et al. 2002). 


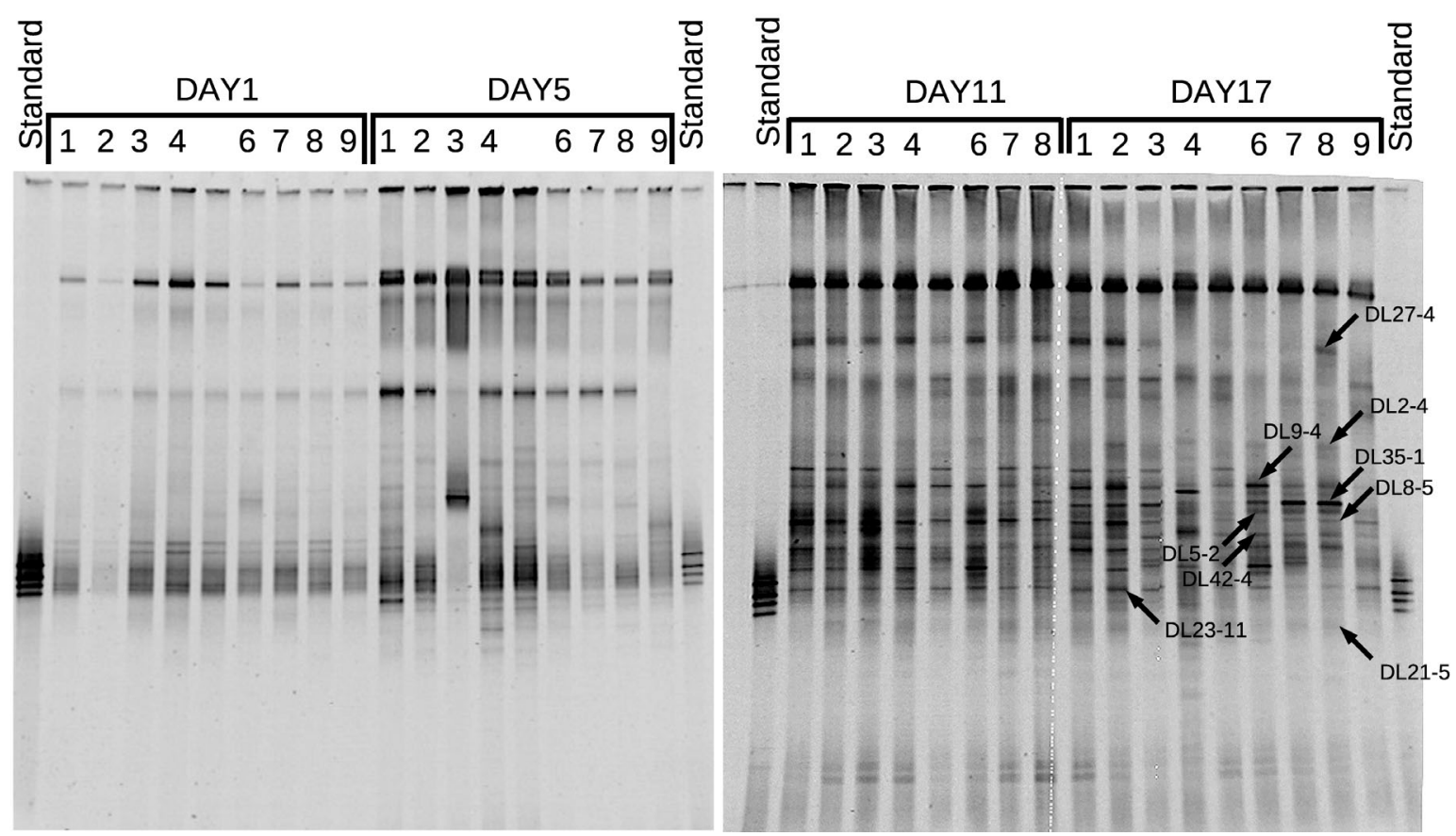

Fig. 3. Community composition of bacteria in the mesocosms. Lane numbers of DGGE gel image correspond to mesocosms, 1: NP, 2: N, 3: P, 4: 5N, 5: 5P, 6: 5NG, 7: 5PG, 8: NPG, and 9: control (see Table 1 for abbreviations). Position of selected 6 Bacteroidetes pylotypes are labeled by arrows: DL2-4: Lewinella sp., DL5-2: uncultured environmental Sphingobacteriales, DL9-4: uncultured environmental Bacteroidetes, DL27-4: uncultured environmental Flavobacteriaceae, DL35-1: Algoriphagus sp., DL42-4: uncultured environmental Sphingobacteriales, DL8-5: Roseobacter sp., DL21-5: Aquiluna sp., and DL23-11: uncultured environmental Betaproteobacteria

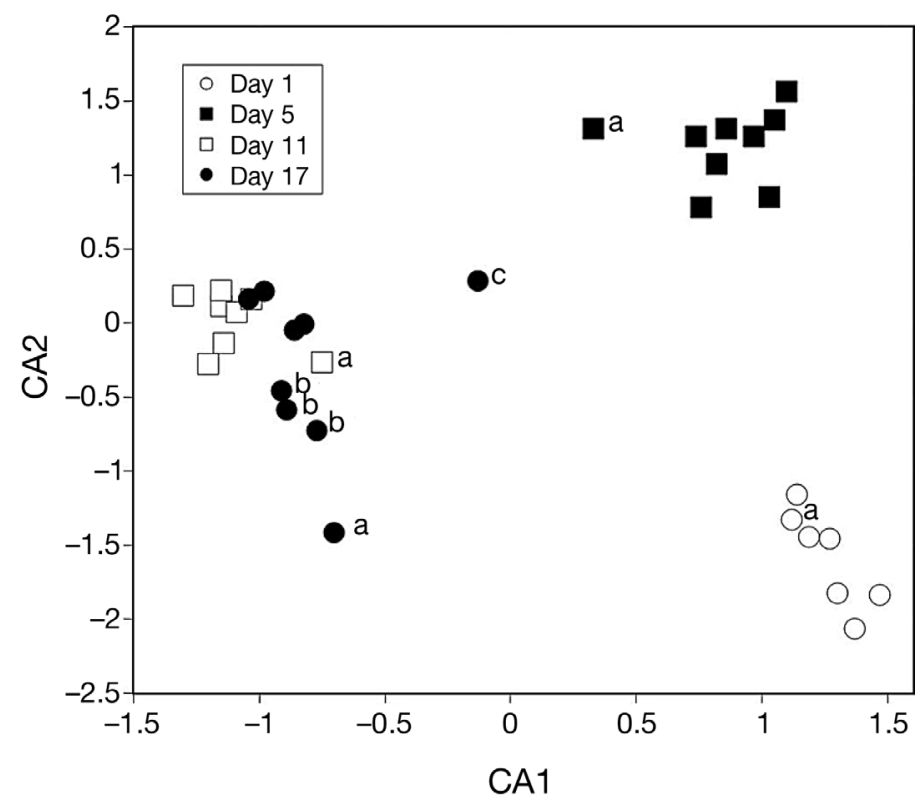

Fig. 4. Correspondence analysis sample (column) scores of the DGGE band pattern. CA1: correspondence component 1 (14.4\% of variation), CA2: correspondence component 2

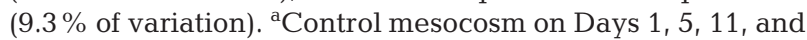
17. ${ }^{\mathrm{b}}$ Glucose mesocosms on Day 17 (significantly different at $\mathrm{p}<0.05$ ). ${ }^{\mathrm{c}} 5 \mathrm{~N}$ mesocosm on Day 17 (significantly different at $\mathrm{p}<0.05)$

\section{The rise of filamentous bacteria}

Neither mineral nutrient additions alone nor the development of a cyanobacterial bloom were sufficient to induce the formation of filamentous cells. A similar increase in BBfila in all glucose mesocosms indicated that the enlarged cells grew on glucose when the supply of external $\mathrm{N}$ or $\mathrm{P}$ was cut or reduced, likely as a consequence of unbalanced substrate availability as found in previous studies (Havskum et al. 2003, Alonso-Saez et al. 2009, Töpper et al. 2010). Our results clearly support the view that marine bacterial communities can go through important morphological changes such as filamentation after episodes of C-source enrichment such as glucose (Alonso-Saez et al. 2009).

We believe that the life strategy of the filamentous bacteria was similar to what was first proposed by Øvreås et al. (2003) and theoretically evaluated by Thingstad et al. (2005). Any strategy by which cell surface area can be increased gives a competitive advantage, provided the cellular requirement for the limiting nutrient does not increase proportionally. The filamentous heterotrophic bacteria have adopted this strategy. By increasing their cell size, filamentous bacteria combine the best of both worlds, simul- 


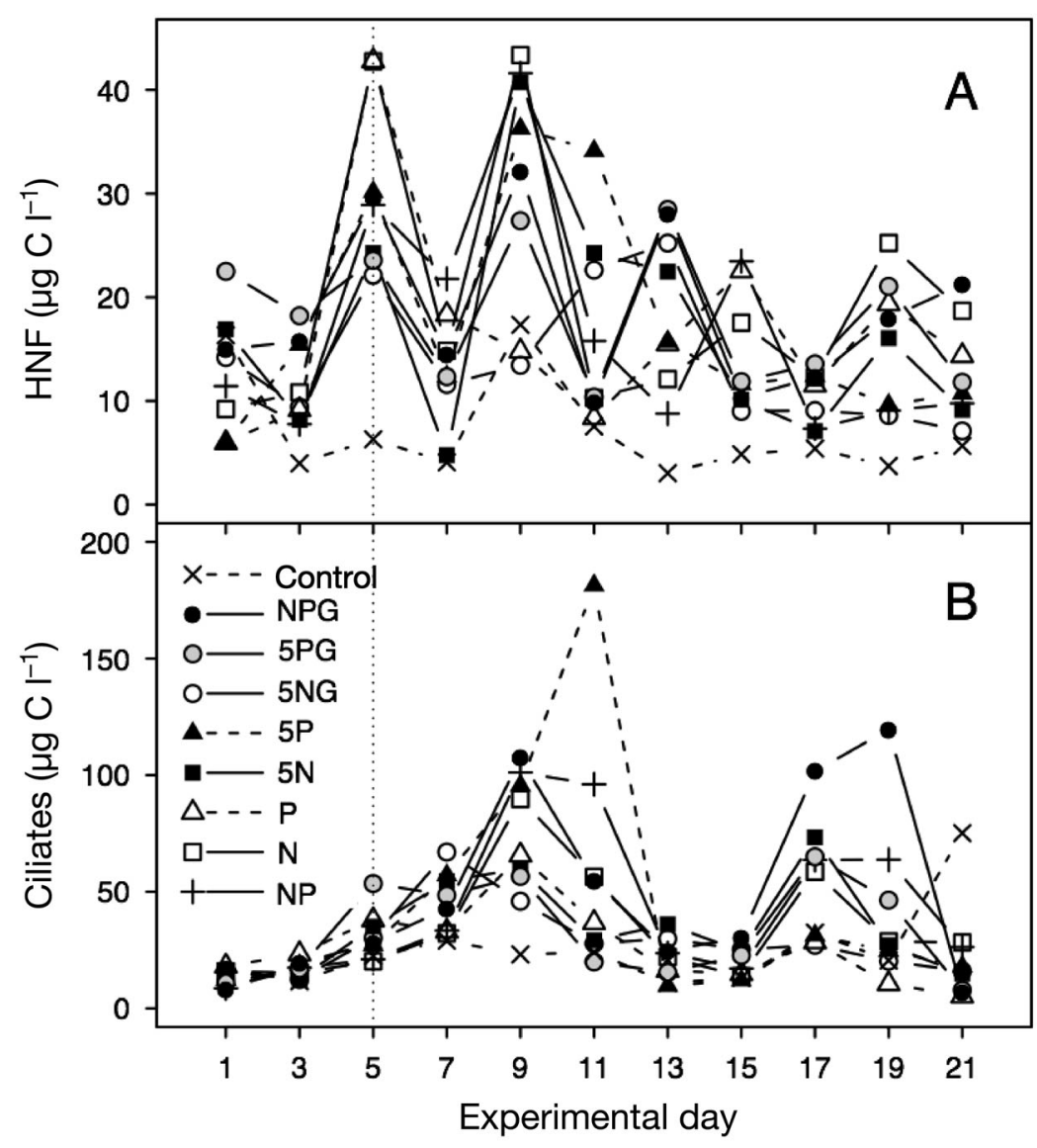

Fig. 5. Dynamics of (A) heterotrophic nanoflagellates (HNF) and (B) ciliate biomass in the mesocosms. Treatment abbreviations as in Table 1

of grazing-resistant morphology is a frequently described mechanism of bacterial filamentation and aggregate formation (Hahn \& Höfle 2001, Pernthaler 2005, Alonso-Saez et al. 2009). It has frequently been observed in lakes, where grazing-resistant filamentous bacteria can temporarily attain high biomass (Pernthaler et al. 2004, Schauer \& Hahn 2005). In coastal waters, including the Baltic Sea, the filamentous bacteria have been observed infrequently (Havskum \& Hansen 1997, Engström-Öst et al. 2002).

The few available experimental studies confirm that filamentous bacteria develop preferentially when a non-balanced organic C substrate, such as glucose, is added (Lebaron et al. 1999, Havskum et al. 2003, Jansson et al. 2006, Alonso-Saez et al. 2009). Alonso-Saez et al. (2009) suggest that glucose forces the bacterial community to a situation of starvation by the limitation of other essential nutrients like $\mathrm{N}$ or $\mathrm{P}$. This is in accordance with experiments where $\mathrm{N}$ and $\mathrm{P}$ starvation caused increased cell volume and filamentation (Holmquist \& Kjelleberg 1993). In contrast, a mixed substrate rich in nutrients,

taneously increasing competitive ability for nutrient uptake and reducing predator vulnerability, thus removing the trade-off between the 2 strategies of being either uptake specialists or defense specialists (Thingstad et al. 2005). Conventionally, nutrientuptake specialists would be interpreted as selecting for small-sized cells. However, if filamentous bacteria have large organic $\mathrm{C}$ inclusions within the cells (Fagerbakke et al. 1996, Casamayor et al. 2000), the cellular C:N:P ratio would be high, and concomitantly the cellular requirements for mineral nutrients low. Using non-limiting glucose to increase size thus gives a 3-fold advantage: increased affinity, decreased predation pressure, and energy storage for later use when environmental conditions change (Thingstad et al. 2005).

The grazer community (HNF, ciliates, mesozooplankton) was remarkably similar between the mesocosms throughout the experiment (Kangro et al. 2007) and could not explain the dominance of the filamentous bacteria in the glucose mesocosms. Development labile C-source, and growth factors, e.g. yeast extract, induces high BP of mostly small and freely dispersed and potentially edible cells (Alonso-Saez et al. 2009). The oligotrophic open ocean may be an exception, where the very distinct bacterial community does not respond to glucose addition with filamentation (Jürgens et al. 2000).

\section{Bacteria interacting with phytoplankton}

Additions of $\mathrm{N}$ led to $\mathrm{P}$ limitation of the planktonic community and vice versa, and glucose addition further added to the nutrient stress (Tanaka et al. 2006). This gradient of nutrient limitations had a clear effect on the phytoplankton community composition (Kangro et al. 2007), and also was reflected by the diagnostic tools for detecting $\mathrm{P}$ limitation among phytoplankton and bacteria (Tanaka et al. 2y006). The unifying response of the phytoplankton community in all mesocosms, further stimulated by warm weather, 
was the development of diazotrophic cyanobacteria, which are autonomous in $\mathrm{N}$ acquisition and have flexible P metabolism strategies (Kangro et al. 2007).

Bacteria have a higher surface:volume ratio than eukaryotic phytoplankton and are therefore more efficient competitors for inorganic nutrients, leading to an advantage when nutrients become limiting. This explains why bacteria have outcompeted phytoplankton in several mesocosm experiments enriched with mineral nutrients and glucose (Havskum et al. 2003, Øvreås et al. 2003, Töpper et al. 2010). In the present study, the glucose effect on bacteria was obvious, but cutting one of the inorganic nutrients only marginally affected the biomass, production, and composition of bacteria. This is in contrast to the clear effect of nutrient limitation on phytoplankton, which was manifested in changes in total biomass, species composition, as well as resting stage production (Olli et al. 2005, Kangro et al. 2007). The increase in the final week of filamentous diazotrophic cyanobacteria in all the mesocosms was paralleled by an increase of $\mathrm{BP}$ in all $\mathrm{P}$ mesocosms and the control. We believe that $\mathrm{N}$, fixed by diazotrophs, became exceedingly available to the heterotrophic bacteria and confounded the effect of mineral nutrient limitation. This indicates that $\mathrm{N}_{2}$-fixing cyanobacteria are an immediate source of bioavailable $\mathrm{N}$ in the Baltic Sea, as suggested by Hietanen et al. (2002).

\section{Community composition}

Earlier studies on bacterial communities in the Baltic Sea noted a prominent presence of members of the Alphaproteobacterial genus Sphingomonas and the Gammaproteobacterial genera Pseudomonas and Shewanella but a lack of typical marine genera of Gammaproteobacteria (Vibrio, Pseudoalteromonas, and Alteromonas) (Hagström et al. 2000). The surface water of the central Baltic Sea is dominated by Bacteroidetes but also hosts typical freshwater phylogenetic groups within Actinobacteria, Verrucomicrobia, and Betaproteobacteria (Riemann et al. 2008, Herlemann et al. 2011).

The community composition of the bacterioplankton in the mesocosms was comparable to recent metagenomic studies from the Baltic Sea (Andersson et al. 2010, Herlemann et al. 2011), being dominated by various Actinobacteria, Alpha- and Betaproteobacteria, and Bacteroidetes phylotypes. Nutrient enrichment and subsequent development of the phytoplankton community changed the bacterial assemblage, resulting in significantly different community composition in the control mesocosm from Day 5 onwards. This might be explained by the differential growth rates of various bacterial groups as a function of changes in dissolved organic matter (DOM) availability (Alonso-Saez et al. 2009, Teira et al. 2009). Dominance of Bacteroidetes phylotypes characterized the glucose mesocosms, which developed a statistically different community composition by Day 17 . This result remains controversial, as the Bacteroidetes group has been associated with phytoplankton blooms (Riemann et al. 2000) and uptake of polymeric organic protein-like substances (Teira et al. 2009), while showing low activity in glucose uptake (Alonso-Saez \& Gasol 2007).

However, the main source of variability, even in the control mesocosm, was the temporal shift in bacterial community composition. This indicates that the short-term variability in bacterial community composition is determined by factors other than nutrient availability. The temporal shift in bacterial composition may have been caused by the gradual build-up of diazotrophic cyanobacterial biomass, and subsequent increased supply of resources to heterotrophic bacteria. Also, changes in the abundance and composition of grazer communities could have shaped the bacterial community composition temporal dynamics. Both, increase of diazotrophic cyanobacterial biomass and shifts in grazer communities, followed similar temporal patterns in all the mesocosms (Kangro et al. 2007).

Acknowledgements. This work was supported by the EU (contract EVK3-CT-2001-00049 'DANLIM'), European Regional Development Fund (Center of Excellence FIBIR and Center of Excellence Chemical Biology), and Estonian Science Foundation (grant 7787). We thank the DANLIM team for valuable discussions and cooperation. We acknowledge Tvärminne Zoological Station (University of Helsinki) for providing laboratory space and a good work environment during the experiment. We are grateful to J. Kiprovskaja (University of Tartu, Institute of Technology) for lab assistance and to A. Kaasik (University of Tartu) for statistical advice. The constructive remarks of 4 anonymous reviewers improved the manuscript.

\section{LITERATURE CITED}

Alonso-Saez L, Gasol JM (2007) Seasonal variations in the contributions of different bacterial groups to the uptake of low molecular-weight compounds in northwestern Mediterranean coastal waters. Appl Environ Microbiol 73:3528-3535

Alonso-Saez L, Unanue M, Latatu A, Azua I, Ayo B, Artolozaga I, Iriberri J (2009) Changes in marine prokaryotic community induced by varying types of dissolved organic matter and subsequent grazing pressure. J Plankton Res 31:1373-1383 
Andersson AF, Riemann L, Bertilsson S (2010) Pyrosequencing reveals contrasting seasonal dynamics of taxa within Baltic Sea bacterioplankton communities. ISME J 4: 171-181

> Bernard L, Courties C, Duperray C, Schafer H, Muyzer G, Lebaron P (2001) A new approach to determine the genetic diversity of viable and active bacteria in aquatic ecosystems. Cytometry 43:314-321

Boenigk J, Stadler P, Wiedlroither A, Hahn MW (2004) Strain-specific differences in the grazing sensitivities of closely related ultramicrobacteria affiliated with the Polynucleobacter cluster. Appl Environ Microbiol 70: 5787-5793

- Bratbak G (1985) Bacterial biovolume and biomass estimations. Appl Environ Microbiol 49:1488-1493

Bratbak G, Thingstad TF (1985) Phytoplankton-bacteria interactions: an apparent paradox? Analysis of a model system with both competition and commensalism. Mar Ecol Prog Ser 25:23-30

Brinkhoff T, Muyzer G (1997) Increased species diversity and extended habitat range of sulfur-oxidizing Thiomicrospira spp. Appl Environ Microbiol 63:3789-3796

> Casamayor EO, Nunez-Cardona MT, Calderon-Paz JI, Mas J, Pedros-Alio C (2000) Comparison of pure cultures and natural assemblages of planktonic photosynthetic sulfur bacteria by low molecular mass RNA fingerprinting. FEMS Microbiol Ecol 32:25-34

> Corno G, Jürgens K (2006) Direct and indirect effects of protist predation on population size structure of a bacterial strain with high phenotypic plasticity. Appl Environ Microbiol 72:78-86

> Engström-Öst J, Koski M, Schmidt K, Viitasalo M and others (2002) Effects of toxic cyanobacteria on a plankton assemblage: community development during decay of Nodularia spumigena. Mar Ecol Prog Ser 232:1-14

Fagerbakke K, Heldal M, Norland S (1996) Content of carbon, nitrogen, oxygen, sulfur and phosphorus in native aquatic and cultured bacteria. Aquat Microb Ecol 10: $15-27$

Fenchel T (1980) Relation between particle size selection and clearance in suspension-feeding ciliates. Limnol Oceanogr 25:733-738

Grasshoff K, Ehrhardt M, Kremling K, Anderson LG (1983) Methods of seawater analysis. Verlag Chemie, Weinheim

> Hagström A, Pinhassi J, Zweifel UL (2000) Biogeographical diversity among marine bacterioplankton. Aquat Microb Ecol 21:231-244

Hahn MW, Höfle MG (2001) Grazing of protozoa and its effect on populations of aquatic bacteria. FEMS Microbiol Ecol 35:113-121

Havskum H, Hansen AS (1997) Importance of pigmented and colourless nano-sized protists as grazers on nanoplankton in a phosphate-depleted Norwegian fjord and in enclosures. Aquat Microb Ecol 12:139-151

> Havskum H, Thingstad TF, Scharek R, Peters F and others (2003) Silicate and labile DOC interfere in structuring the microbial food web via algal-bacterial competition for mineral nutrients: results of a mesocosm experiment. Limnol Oceanogr 48:129-140

> Herlemann DPR, Labrenz M, Jürgens $\mathrm{K}$, Bertilsson S, Waniek JJ, Andersson AF (2011) Transitions in bacterial communities along the $2000 \mathrm{~km}$ salinity gradient of the Baltic Sea. ISME J 5:1571-1579

> Hietanen S, Moisander PH, Kuparinen J, Tuominen L (2002)
No sign of denitrification in a Baltic Sea cyanobacterial bloom. Mar Ecol Prog Ser 242:73-82

Holmquist K, Kjelleberg S (1993) Changes in viability, respiratory activity and morphology of the marine Vibrio $\mathrm{sp}$. strain S14 during starvation of individual nutrients and subsequent recovery. FEMS Microbiol Ecol 12:215-223

> Jansson M, Bergstrom AK, Lymer D, Vrede K, Karlsson J (2006) Bacterioplankton growth and nutrient use efficiencies under variable organic carbon and inorganic phosphorus ratios. Microb Ecol 52:358-364

Jumars P, Deming J, Hill P, Karp-Boss L, Dade W (1993) Physical constraints on marine osmotrophy in an optimal foraging context. Mar Microb Food Webs 7:121-161

Jürgens K, Gasol JM, Vaque D (2000) Bacteria-flagellate coupling in microcosm experiments in the Central Atlantic Ocean. J Exp Mar Biol Ecol 245:127-147

Kangro K, Olli K, Tamminen T, Lignell R (2007) Speciesspecific responses of a cyanobacteria-dominated phytoplankton community to artificial nutrient limitation in the Baltic Sea. Mar Ecol Prog Ser 336:15-27

Koch AL (1996) What size should a bacterium be? A question of scale. Annu Rev Microbiol 50:317-348

Larsen A, Flaten GAF, Sandaa RA, Castberg T and others (2004) Spring phytoplankton bloom dynamics in Norwegian coastal waters: microbial community succession and diversity. Limnol Oceanogr 49:180-190

> Lebaron P, Servais P, Troussellier M, Courties C and others (1999) Changes in bacterial community structure in seawater mesocosms differing in their nutrient status. Aquat Microb Ecol 19:255-267

> Lignell R, Hoikkala L, Lahtinen T (2008) Effects of inorganic nutrients, glucose and solar radiation on bacterial growth and exploitation of dissolved organic carbon and nitrogen in the northern Baltic Sea. Aquat Microb Ecol 51: 209-221

Ludwig W, Strunk O, Westram R, Richter L and others (2004) ARB: a software environment for sequence data. Nucleic Acids Res 32:1363-1371

Muyzer G, Dewaal EC, Uitterlinden AG (1993) Profiling of complex microbial populations by denaturing gradient gel electrophoresis analysis of polymerase chain reaction-amplified genes coding for 16S rRNA. Appl Environ Microbiol 59:695-700

Olli K, Seppälä J (2001) Vertical niche separation of phytoplankton: large-scale mesocosm experiments. Mar Ecol Prog Ser 217:219-233

Olli K, Heiskanen AS, Seppälä J (1996) Development and fate of Eutreptialla gymnastica bloom in nutrient enriched enclosures in the coastal Baltic Sea. J Plankton Res 18:1587-1604

> Olli K, Kangro K, Kabel M (2005) Akinete production of Anabaena lemmermannii and A. cylindrica (Cyanophyceae) in natural populations of N- and P-limited coastal mesocosms. J Phycol 41:1094-1098

- Øvreås L, Bourne D, Sandaa RA, Casamayor EO and others (2003) Response of bacterial and viral communities to nutrient manipulations in seawater mesocosms. Aquat Microb Ecol 31:109-121

Parsons TR, Albright LJ, Whitney F, Wong CS, Williams PJL (1981) The effect of glucose on the productivity of seawater: an experimental approach using controlled aquatic ecosystems. Mar Environ Res 4:229-242

Pernthaler J (2005) Predation on prokaryotes in the water column and its ecological implications. Nat Rev Microbiol 3:537-546 
Pernthaler J, Zollner E, Warnecke F, Jürgens K (2004) Bloom of filamentous bacteria in a mesotrophic lake: identity and potential controlling mechanism. Appl Environ Microbiol 70:6272-6281

Pinhassi J, Zweifel UL, Hagström A (1997) Dominant marine bacterioplankton species found among colony-forming bacteria. Appl Environ Microbiol 63:3359-3366

R Development Core Team (2011) R: a language and environment for statistical computing. R Foundation for Statistical Computing, Vienna. www.R-project.org

Riemann B, Bjornsen PK, Newell S, Fallon R (1987) Calculation of cell production of coastal marine-bacteria based on measured incorporation of $\left[{ }^{3} \mathrm{H}\right]$ thymidine. Limnol Oceanogr 32:471-476

Riemann L, Steward GF, Azam F (2000) Dynamics of bacterial community composition and activity during a mesocosm diatom bloom. Appl Environ Microbiol 66: 578-587

Riemann L, Leitet C, Pommier T, Simu K, Holmfeldt K, Larsson U, Hagström A (2008) The native bacterioplankton community in the central Baltic Sea is influenced by freshwater bacterial species. Appl Environ Microbiol 74: 503-515

Rink B, Seeberger S, Martens T, Duerselen CD, Simon M, Brinkhoff T (2007) Effects of phytoplankton bloom in a coastal ecosystem on the composition of bacterial communities. Aquat Microb Ecol 48:47-60

Schauer M, Hahn MW (2005) Diversity and phylogenetic affiliations of morphologically conspicuous large filamentous bacteria occurring in the pelagic zones of a broad spectrum of freshwater habitats. Appl Environ Microbiol 71:1931-1940

Smayda TT (2002) Adaptive ecology, growth strategies and the global bloom expansion of dinoflagellates. J Oceanogr 58:281-294

Smetacek V, Assmy P, Henjes J (2004) The role of gazing in structuring Southern Ocean pelagic ecosystems and biogeochemical cycles. Antarct Sci 16:541-558

Smith D, Azam F (1992) A simple, economical method for measuring bacterial protein synthesis in seawater using 3H-leucine. Mar Microb Food Webs 6:107-114

Stevens H, Brinkhoff T, Simon M (2005) Composition of freeliving, aggregate-associated and sediment surface-associated bacterial communities in the German Wadden Sea. Aquat Microb Ecol 38:15-30

Tanaka T, Henriksen P, Lignell R, Olli K, Seppälä J, Tamminen T, Thingstad F (2006) Specific affinity for phosphorus uptake and specific alkaline phosphatase activity as diagnostic tools for detecting phosphorus-limited phytoplankton and bacteria. Estuar Coasts 29:1226-1241

- Teira E, Martínez-García S, Lønborg C, Álvarez-Salgado XA (2009) Growth rates of different phylogenetic bacterioplankton groups in a coastal upwelling system. Environ Microbiol Rep 1:545-554

> Thingstad TF, Øvreås L, Egge JK, Lovdal T, Heldal M (2005) Use of non-limiting substrates to increase size; a generic strategy to simultaneously optimize uptake and minimize predation in pelagic osmotrophs? Ecol Lett 8:675-682

Töpper B, Larsen A, Thingstad F, Thyrhaug R, Sandaa RA (2010) Bacterial community composition in an Arctic phytoplankton mesocosm bloom: the impact of silicate and glucose. Polar Biol 33:1557-1565

> Tuomi P, Lundsgaard C, Ekebom J, Olli K, Künnis K (1999) The production and potential loss mechanisms of bacterial biomass in the southern Gulf of Riga. J Mar Syst 23: 185-196 


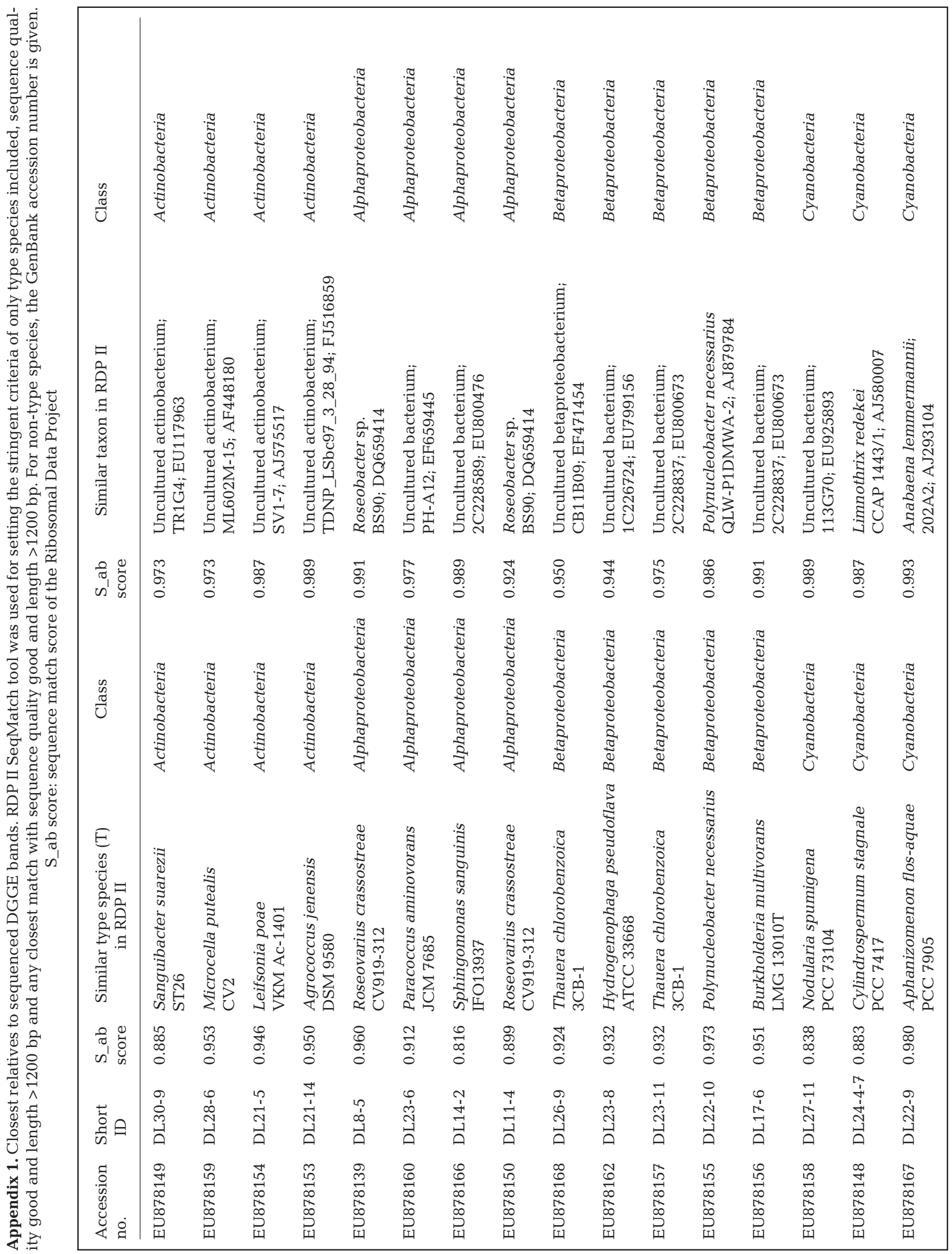




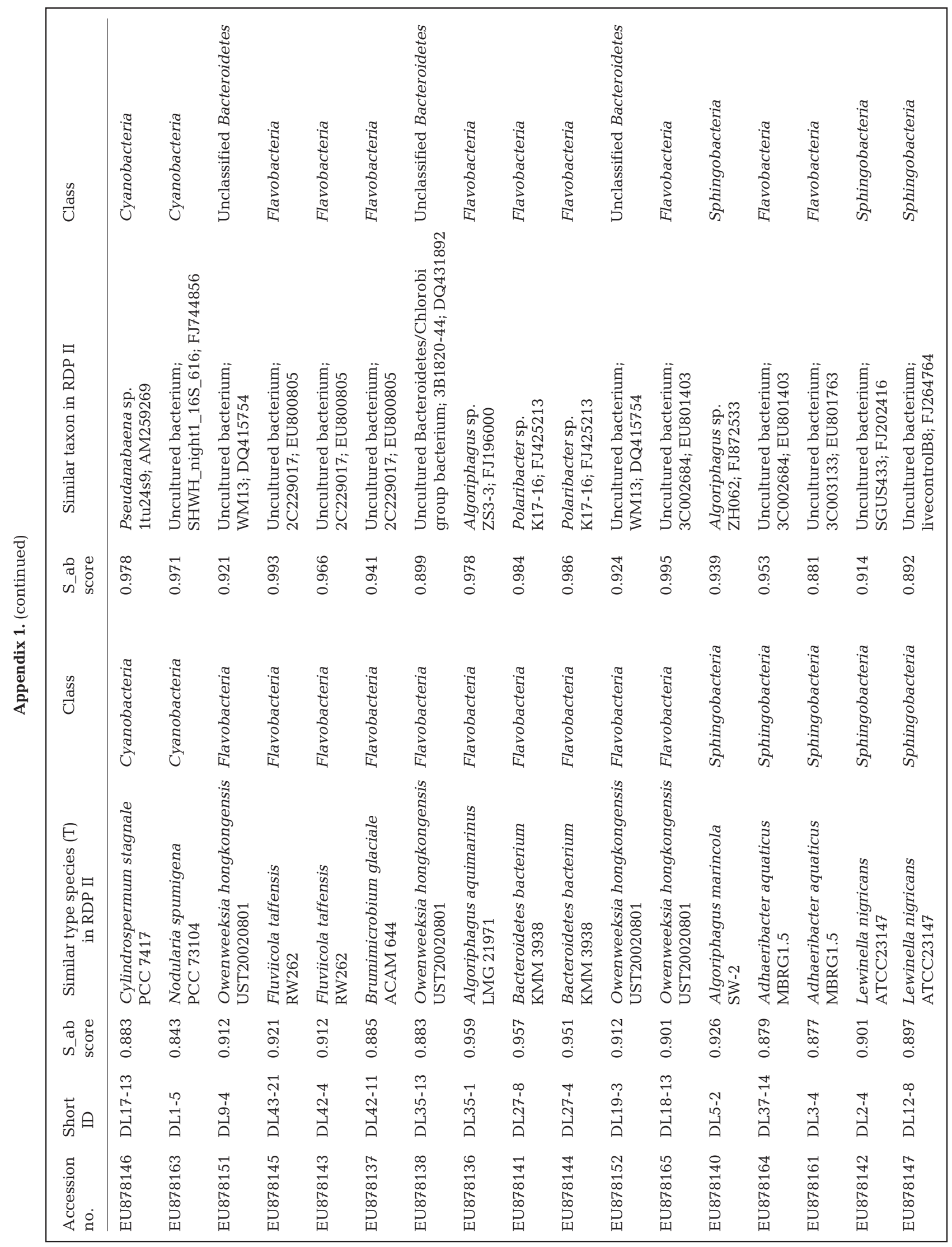

